\title{
ON THE DEVELOPMENT OF THE 'THYROID WEIGHT IN THE DAIRY HERD OF THE VIIK EXPERIMENTAL FARM
}

\author{
VAPPU Kossila \\ Department of Animal Husbandry, University of Helsinki
}

Received Feb:uary 25, 1969

The results of an earlier study indicated that the weight and the epithelial tissue content of the thyroid were significantly smaller in cows and young cattle discarded from the dairy herd of the Viik Experimental Farm during the years 1960 - 65 (group II) than correspondingly in those discarded during 1958-59 (group I) (Kossila 1967 b). These differences in the thyroid characteristic between the groups I and II were believed to be due mainly to the addition of supplementary iodine into the ration of the herd since the year 1959 . In the cow, the fetal period is evidently the most critical in iodine deficiency. Possible malformations in the thyroid, developed during this period, are obviously not completely reversed back to what we call normal by the addition of sufficient amounts of iodine into the diet during the later periods of life. Since most of the cows in group II were born before the iodized mineral salt mixture was introduced to the ration of the herd, it seemed that a further reduction, especially in the thyroid weight of the cows, could be quite possible. In order to find out whether this was so thyroid studies were carried out in the same herd for nearly four more years.

\section{Material and methods}

Details concerning the feeding and management of the Ayrshire herd of the Viik Experimental Farm have been described earlier (Kossila 1967a, p. 32-36), and so far these conditions have remained more or less unchanged. The few nutritional details that have been introduced since 1965, have been as follows: (a) The cows approaching parturition have received two vitamin injections, each consisting of 5 million units of vitamin $\mathrm{D}_{3}$, 1.5 million units of vitamin A, and $250 \mathrm{mg}$ of vitamin $\mathrm{E}$. This treatment has been applied in order to prevent parturient paresis and to improve the nutritional status of the cows at calving. Before 1965, only vitamin $\mathrm{D}_{3}$ was used correspondingly. (b) Propylenglycol has

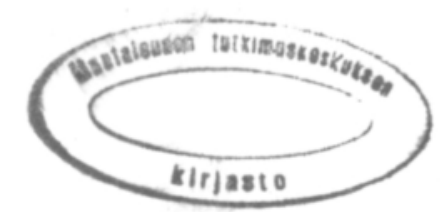




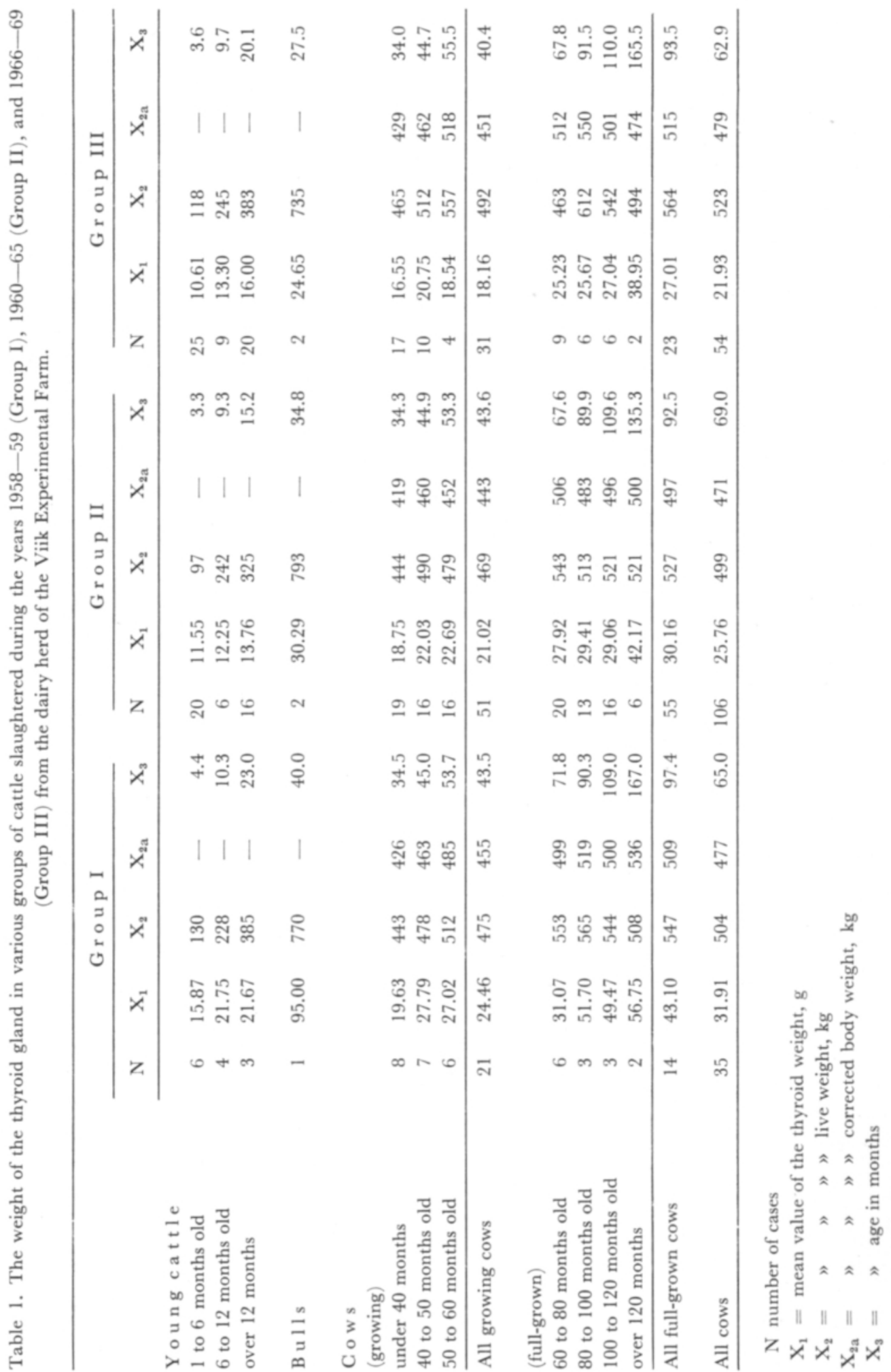


been used lately in order to prevent acetonemia in post parturient cows exhibiting signs of this metabolic disturbance. (c) Wheat bran formerly used in the concentrate mixture has been replaced by oat- and barley-meals.

The thyroid samples were handled as previously described (Kossila 1967a, p. 36). Altogether 49 thyroid samples had been obtained from animals slaughtered during the years 1958 - 59 (group I) and 150 from those slaughtered during 1960 - 65 (group II). 110 additional samples were obtained from animals slaughtered during 1966-69 (group III) (Table 1). Live weight and, for cows, also corrected body weight, were determined in a manner previously described (KossiLA 1967 a. p. 37-38). The ages of the animals varied from 1 month to 208 months. The animals were divided into several subgroups according to their age as shown in Table 1. The age-groups of animals 1 to 6 months old and 6 to 12 months old included both sexes, whereas the age-group of young cattle over 12 months included only heifers.

\section{Results}

The results obtained for the groups I, II, and III have been summarized in Table 1. The effect of age on the thyroid weight of the animals belonging to the groups I, II, and III has been illustrated graphically in Fig. 1. It shows that the animals in group I had the heaviest thyroids, on an average, irrespective of age. The difference in thyroid weight between group $\mathrm{I}$ and group II was highly significant in young cattle $(\mathrm{P}<0.001)$ (see Table 1), the difference was not significant in growing cows, but it was again significant in full-grown cows $(\mathrm{P}<0.001)$ as well as in all cows $(\mathrm{P}<0.005)$.

Young cattle in the groups II and III had quite similar thyroid weights (Fig. 1). On the other hand, in growing and in full-grown cows, i.e. as from about 30 months of age, the thyroid weight has been consistently lower in group III than in group II. Even though this difference between the two groups is relatively small, it nevertheless shows that the tendency for the thyroid weight to decrease since 1960-65 has persisted.

In all cows, the mean thyroid weight was $31.91 \mathrm{~g}$ in group $\mathrm{I}, 25.76 \mathrm{~g}$ in group II, and $21.93 \mathrm{~g}$ in group III (Table 1). Thus the decrease in the thyroid weight of cows has been $6.15 \mathrm{~g}$ from the first to the second phase of the study and $3.83 \mathrm{~g}$ from the second to the third phase of the study, on an average. Furthermore, the values in Table 1 show that the thyroid weight has decreased more in full-grown than in growing cows.

In groups II and III, there appears to be a tendency for the thyroid weight to remain constant after the cows have completed growth, i.e. approximately from the age of 65 months on. However, the cows over 120 months old have still had rather high thyroid weights (Fig. 1) in spite of the fact that they have received supplemental iodine in some cases during several years.

\section{Discussion}

The results of this study show that the thyroid weight of the cows belonging the dairy herd of the Viik Experimental Farm has continued to decrease during the last few years even though the rate of decrease has somewhat slowed down. Obviously the decrease in the thyroid weight has occurred as a result of the addition of an iodized mineral salt mixture 


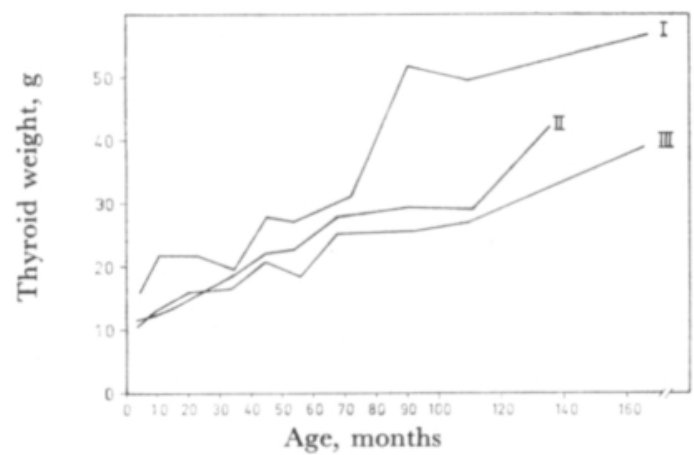

Fig. 1. Effect of age on the thyroid weight in cattle slaughtered during the years 1958-59 (group I), 1960-65 (group II), and 1966-69 (group III) from the dairy herd of the Viik Experimental Farm.

into the ration of the herd since 1959 (Kossila 1967 a, p. 34-35). This theory is also supported by the results obtained from histological studies, which revealed significantly more epithelial tissue in grams per thyroid gland of the animals belonging to group I as compared with those belonging to group II (Kossila 1967 a, p. 78-79). It is well known that iodine deficiency results in an increase of the weight and the epithelial tissue content of the thyroid. It should be emphasized that hardly any such feeds, as are known to contain considerable amount of goitrogens (rutabagas, swedes, marrowstem kale), have been fed to the cows in question. An exception to this rule was made during the winterfeeding period 1967-68, when silage, which contained marrowstem kale and beet tops in a ratio of $1: 1$, was fed at a rate of approximately $20 \mathrm{~kg} / \mathrm{cow} /$ day during a four month period. If this silage has had any effect on the thyroid weight, it has affected only the animals in group III.

Most of the thyroids of the full-grown cows in group I exhibited signs of struma hypoepithelialis medio- \& macrofollicularis according to the classification of Uotila (1957), whereas most of those in group III examined so far could be classified correspondingly as struma normoepithelialis mediofollicularis. Obviously the iodine prophylaxis, applied since 1959, has been beneficial in preventing the development with age of colloid goiter in cows. The fact that the oldest cows in groups II and III have still had rather high thyroid weights is not surprising since these cows were already born before the feeding of supplemental iodine was begun.

The absolute weight of the thyroid is related to the body weight of the cows. Furthermore, the weight of the gland appears to be more closely related to the corrected body weight than to the live weight of the cows (Kossina 1967 a, p. 73-74). Results presented in Table 1 show, however, that the mean corrected body weight of all cows has been approximately the same in groups I, II, and III.

There is no direct evidence so far that would indicate that the various treatments, introduced since 1965 in order to improve the nutritional status of the cows, would have exerted any influence on their thyroid weights. On the other hand, there is reason to believe that at least the propylenglycol treatment has been beneficial in improving the lectational performance of especially such cows that otherwise would have suffered from acetonemia.

It is well known by now that the growth (TURNer 1965) and secretion of milk (TURNER 1963) of the mammary gland are largely controlled by endocrine factors including thyroid function (Turner 1968). It has been noted that the capacity of milk production of the 
herd in question has increased markedly since 1958. According to the herd records, the cows produced an average of $4738 \mathrm{~kg}$ milk and $223 \mathrm{~kg}$ butterfat during the control year 1958 - 59 and $6268 \mathrm{~kg}$ and $285 \mathrm{~kg}$ respectively during $1967-68$. Judging by the above observations and by results obtained earlier (Kossila 1967 b), a thyroid with weight and structural characteristics close to what we consider normal (glandula thyreoidea normoepithelialis mediofollicularis) is obviously an indicator of higher hormonal efficiency from the point of view of maintaining the milk secretion in cows at an optimal level than a thyroid with weight and/or structural characteristics deviating considerably from normal (struma hypoepithelialis medio- \& macrofollicularis or struma hyperepithelialis micro- \& mediofollicularis).

\section{S $u m m$ ary}

The mean thyroid weight of the growing (under 60 months old) and full-grown (over 60 months old) cows slaughtered from the Ayrshire herd of the Viik Experimental Farm during the years 1958-59 (I), 1960 - 65 (II) and 1966-69 (III) was as follows: 24.46 and $43.10 \mathrm{~g}$ (I), 21.02 and 30.16 (II) and 18.16 and $27.01 \mathrm{~g}$ (III) respectively. Decrease in the thyroid weight from (I) to (III) was believed to be due to the adding of iodine as a component of a mineral salt mixture into the ration of the herd in 1959. The thyroid weights of young cattle and bulls showed trends similar to those observed in cows.

\section{REFERENCES}

Kossil.A, V. 1967a. On the weight and basic structural components of the thyroid in dairy cattle. Acta Agr. Fennica 109, 2 pp. 115.

- - 1967b. Jodintarpeen tyydyttämisen merkitys lypsylehmien ravitsemuksessa. Summary: The role of iodine in the nutrion of dairy cows. Maatal. ja Koetoim. 21: 228-233.

Turner, C. W. 1963. What causes high production? Study of the role endocrine glands play in milk secretion. Mo. Agr. Exper. State Bull. 795.

- - 1965. What causes high production? Story of the role of the endocrine glands in udder growth. Ibid. 793.

-n - 1968. What causes high production? Story of the role of the thyroid glands in milk secretion. Ibid. 871.

UotilA, U. 1957. Thyreoideas histofysiologi. Nord. Med. 57: 809.

\section{SELOSTUS}

\section{KILPIRAUHASPAINON KEHITTYMISESTÄ VIIKIN OPETUS- JA KOETILAN LYPSYKARJASSA}

VAPPU Kossila

Helsingin yliopiston kotieläintieteellinen laitos

Vuosina 1958 - 59 (I), 1960-65 (II) ja 1966-69 (III) Viikin opetus- ja koetilan Ayrshire-karjasta alle 60 kk:n ikäisenä eli kasvavana ja yli 60 kk:n ikäisenä eli täysikasvuisena poistettujen lehmien kilpirauhasten paino oli keskimäärin (I) 24.46 ja $43.10 \mathrm{~g}$, (II) 21.02 ja $30.16 \mathrm{~g}$, (III) 18.16 ja $27.01 \mathrm{~g}$ vastaavasti. Kilpirauhaspainon alentuminen I:stä III:een uskotaan johtuneen lähinnä siitä, että ko. karjalle ryhdyttiin vuonna 1959 syöttämään jodisoitua kivennäissuolaseosta. Nuorella karjalla ja sonneilla on todettu samansuuntaista kehitystä kilpirauhaspainossa kuin lehmilläkin. Tutkimuksessa on kiinnitetty myös huomiota kilpirauhasen mikroskooppiseen rakenteeseen.

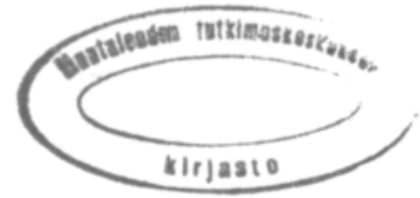

